\title{
Contributions on human fascioliasis and its snail intermediate host in Nile Delta, Egypt
}

\author{
Mohamed M. El-Bahy ${ }^{1}$, Abeer M. A. Mahgoub ${ }^{2 *}$, Eman E. Taher ${ }^{3}$ \\ ${ }^{I}$ Department of Parasitology, Faculty of Veterinary Medicine, Cairo University \\ ${ }^{2}$ Department of Parasitology, Faculty of Medicine, Cairo University \\ ${ }^{3}$ Research Institute of Ophthalmology, El-Giza, Egypt \\ *Corresponding author E-mail: goubya@hotmail.com
}

Copyright $\odot 2014$ El-Bahy et al. This is an open access article distributed under the Creative Commons Attribution License, which permits unrestricted use, distribution, and reproduction in any medium, provided the original work is properly cited.

\begin{abstract}
The present study spotted some light on human fascioliasis in Kafr El-Sheikh Governorate in the west of the Nile Delta in Egypt, its species, its intermediate host (IMH) snail and tried to answer previous questions about development of Fasciola $(F$.) species in new snail hosts other than that known for animal fascioliasis in Egypt.

The study recorded a percentage of infection by Fasciola eggs reached up to $6.02 \%$ in 1810 randomly collected human stool samples from 6 climatically selected sites in this governorate using fluke-finder technique. The incidence was high in Sedi Salem and Motobus than in the other study sites. Micrometry measuring of 100 eggs from each locality showed that egg size cannot be used as a main criterion in differentiation between F. hepatica and gigantica. Wide range of egg size varied between 130-162.5 $\mu$ X 75-87.5 $\mu$ with a mean length and width of $144.24 \pm 11.33 \mu$ X $80 \pm 6.55 \mu$, was recorded. Upon dissection of 1972 Lymnaea (L.) cailliaudi, 268 L. alexandrina, 502 Bulinus species, 11316 Biomphalaria alexandrina, 1398 Cleopatra species, 8520 Physa acuta, 420 Melania tuberculata, 2132 Vivipara (Bellamya) unicolar, 144 Neritina nilotica and 1570 Planorbis philippi, Fasciola parthenitae were not detected in snails other than L. cailliaudi (the known IMH of Fasciola in Egypt). The results proved that there is no accommodation has occurred in any of the surrounding snails to transmit Fasciola to man. The present study proved that human fascioliasis in the study sites was due to Fasciola gigantica not $F$. hepatica. This appeared in its tendency to develop in $L$. cailliaudi not in other tested snails with successive radial generations as that described previously for $F$. gigantica. Moreover, early mature flukes extracted from laboratory infected rabbits by the produced encysted metacercariae had the characteristic features described previously for $F$. gigantica.
\end{abstract}

Keywords: Cercariae- Egypt- Fasciola gigantica- Human- L. Cailliaudi.

\section{Introduction}

Fascioliasis, an infection due to the food and water-borne trematodes Fasciola hepatica and F. gigantica, is of the most neglected of the neglected tropical diseases [1]. Worldwide, more than 90 million people are at risk of fascioliasis and between 2.4 and 17 million individuals are infected with Fasciola [2]. Fascioliasis in human took special interest during the last several years in the Nile Delta region in Egypt. This is mainly due to increase the percentage of infestation from 8 cases only in Dakahlyia in 1972 [3], to $2.38 \%$ in Cairo and Giza Governorate, Egypt [4] after stool examination. The percentage increased to $15.03 \%$ and $18.12 \%$ in the above two governorates respectively, after using ELISA [4], [5].

There has been speculations about the origin of the species that occurred in human, is it Fasciola hepatica or Fasciola gigantica? With no records for the presence of Lymnaea truncatula in the Nile Valley in previous study sites, and is there another type of snail accommodates to help in completing the cycle of the parasite to infect human as mentioned by Farag and El-Sayed [6].

In the present study field and laboratory work aimed at better defining of Fasciola as a zoonotic problem with special interest to determine IMH snail responsible for spreading of infection to human. Kafr El-Sheikh governorate was selected as a study area, as it is considered to be an ideal habitat for different snails in the Nile Delta [7]. 
These field efforts aimed at determining the status of Fasciola infection in human in 6 selected regions in Kafr El-Sheik governorate. All of the water ways present in the study sites was examined; samples representing from all types of snails present were collected and examined to clarify their role in transmission of Fasciola. In the laboratory snail IMH of human fascioliasis was experimentally determined. Miracidia produced from Fasciola eggs isolated from infected cases were tested to develop in L. cailliaudi, L. truncatula, Bulinus truncatus and Biomphalaria alexandrina snails followed by further development of the produced EMC experimentally in rabbit.

\section{Material and methods}

This study was assessed and approved by Faculty of Medicine Cairo University Ethics Committee, after taking consents from local health authorities and all participants and have been performed in accordance with the ethical standards laid down in the 1964 Declaration of Helsinki. This study was conducted between March 2012 and February 2013.

\section{1 . Field works}

\subsubsection{Selection of the study sites}

Available national satellite data cleared an inverse relation between diurnal temperature difference (dT) in the lower Nile River Valley and the prevalence of Schistosoma infection. This thermal difference values reflect regional hydrologic conditions that can be used as a predictor of environmental risk assessment which depends for some extent on the persistence of the trematoda snail's intermediate hosts [7]. According to this satellite temperature and hydrological data, Kafr El-Sheik governorate has 3 main zones as wet (dT from $\left.12-14{ }^{\circ} \mathrm{C}\right)$, moist $\left(\mathrm{dT}\right.$ from $\left.14-16^{\circ} \mathrm{C}\right)$ and dry (dT from $16-20^{\circ} \mathrm{C}$ ). The study sites were selected to represent these 3 different zones, as Motobus and Sedi Salem represent the wet zone, Shenno and Abioka represent the moist zone while El-Halafy and El-Kafr El-Sharky represent the dry zone.

\subsubsection{Collection and examination of samples}

Through 1-2 visits per month for the local health units and some schools in each of the study sites, a total of identified 1810 human stool samples were collected during this study. Samples were examined in the Department of Parasitology Faculty of Veterinary Medicine, Cairo University for the presence of Fasciola eggs using double sieve system "fluke finder" technique [8] with the aid of methylene blue stain for detection of the eggs under the microscope. The percentage of infection in the examined samples was recorded.

One hundred Fasciola eggs isolated from the infected stool samples were identified [9]. Length and width of each egg were measured using the graduated micrometer slide and eye piece [10].

\subsubsection{Examination of the different water ways}

In cooperation with the Ministry of Health (M.O.H.) Snail Eradication Office in Kafr El-Sheik governorate, samples from all types of snails present in the different water ways within a circle of $2 \mathrm{~km}$ diameter around housed area in each of the study sites were collected and brought to the laboratory. Snails were collected [11] by taking of 2 net samples (at 10 and $30 \mathrm{~cm}$ depth from the water surface) each 50 regular step for each water way. In the laboratory snails were identified [12], [13] and maintained in the laboratory [14] for 7-15 days.

All collected snails were examined for trematoda infection by light exposure and crushing techniques [15]. Different trematodes parthenitae detected were identified [11], [16]; then recorded for each snail species separately

\section{2 . Laboratory experiments}

This part of the study was done to determine the snail IMH of Fasciola that infect human through testing the ability of their miracidia to develop in Lymnaea cailliaudi snail (the known intermediate host for F. gigantica in Egypt), L. truncatula (the known intermediate host of F. Hepatica) as well as in two of Schistosoma snail IMH , Bulinus spp and B. alexanderina. This was followed by infection of rabbits by the produced encysted metacercariae (EMC) for obtaining on mature fluke.

\subsubsection{Laboratory breeding of snails for experimental infection}

Lymnaea cailliaudi, Bulinus truncatus and Biomphalaria alexandrina egg masses were collected from the aquarium of the field collected snails and transferred to another separate one where they were reared [17]. Similarly; large numbers 
of L. truncatula were collected from a site at the end of El-Mansoryea drain near Kerdasa, Giza and established in the laboratory as above. The aquaria were supplied by fine sand brought from their original habitat.

\subsubsection{Separation of Fasciola eggs and production of miracidia}

Fasciola eggs were separated from stool of the infected human patients by successive sieving using the fluke finder after washing by compressed tape water then collected into a separate cylinder. The washed eggs were kept in the refrigerator in distilled water and embryonated in water in the laboratory for production of miracidia.

Embryonation of eggs was done in an incubator at $28^{\circ} \mathrm{C}$ [9]. Eggs were checked daily under the microscope from the $9^{\text {th }}$ day of embryonation after exposure for $1 / 2$ an hour to direct light. The day of hatching was defined as that in which $50 \%$ or more of the eggs hatched at the same time.

\subsubsection{Artificial infection of snails}

Laboratory prepared snails of 4-5 weeks old were tested as IMH. Each snail was exposed overnight to 2-5 miracida in a separate well of tissue culture plate $(12 \mathrm{~mm}$ diameter) [14]. Snails were reared in the laboratory and fed green lettuce. Two infected snails from each group were crushed from the $6^{\text {th }}$ day post- infection (d.p.i.) and every two to three days after this depending on the suspected state of parthenita development inside the snail until the time of first cercarial shedding. Encystment of shed cercariae occurred on cellophane covered containers. Collected encysted metacercariae (E.M.C.) were stored under refrigeration $\left(4^{\circ} \mathrm{C}\right)$ for 5-8 days in water. The species of the EMC was determined by experimental infection of rabbits.

\subsubsection{Infection of rabbits}

To determine the species of Fasciola eggs extracted from human, the EMC produced after laboratory infection of the snails were used for production of fluke in rabbits ( two rabbits for each host origin) as follows:,

Four Boscat rabbits (1.5-2 kg each) each was infected by 15-20 EMC. The EMC dose was wrapped in a piece of lettuce and deposited over the base the tongue, keeping the animal's mouth closed by hand till it was swallowed. Animals were maintained on dry ration and water free choice until the end of the experiment.

Two rabbits died at 45 days post infection. The remaining two were slaughtered on this day also. The liver surface was examined for the presence of necrotic migratory furrows. Necrotic areas were examined for fluke recovery using 2 surgical needles for extraction of the juvenile migrating flukes. The liver was sliced into small pieces where all flukes present in the liver and the peritoneal cavity were collected [14]. The recovered flukes were fixed and mounted on slides [10]. Fluke species was identified [18].

\section{Results}

\subsection{Incidence of Fasciola infections and egg size}

Results of examined human stool samples collected from 6 selected places in Kafr El-Sheikh governorate for the presence of Fasciola eggs were listed in table (1). The mean percentage reached up to $6.02 \%$ of human who shed Fasciola eggs in their feaces. Infection rates were higher in the summer season, reaching $7.69 \%$. The highest number of patients shed Fasciola eggs in their feaces was in Sedi Salem (8.46\%) and Motobus (7.08\%). Results suggested that infection in human is not sex or age dependent.

Measuring the length and width of 100 eggs randomly isolated from infected stool samples revealed a wide size ranged

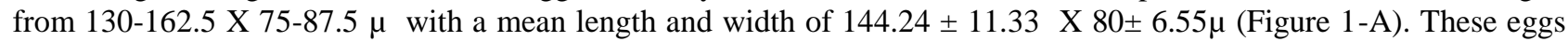
were in six sizes range with different percentages including; $30 \%$ of these eggs with size of $(130-135 \times 75-80 \mu), 20 \%$ of size $(137.5 \times 80 \mu), 20 \%$ of size $(150 \times 80 \mu), 10 \%$ of size $(152.5 \times 87.7 \mu), 10 \%$ of size $(157.5 \times 80 \mu)$ and $10 \%$ of large size $(162.5 \times 82.5 \mu)$.

\subsection{Trematoda infection in snails collected from study sites}

This part of the study focused on examination of different snail species present in each of the study sites to determine if any of them can act as probable IMH for Fasciola species in these localities.

Collection and examination of samples from the available snails species found during the year in the different study sites in Kafr El-Sheikh governorate included 6152 L. cailliaudi snails, 268 L. alexandrina snails, 502 Bulinus species , 11316 Biomphalaria alexandrina, 1398 Cleopatra species, 8520 Physa acuta , 420 Melania tuberculata, 925 Vivipara (Bellamya) unicolar, 144 Neritina nilotica and 1570 Planorbis pheleppi. Table (2) revealed a mean infection rate reached $32.05 \%, 0.0 \%, 11.75 \%, 64.74 \%, 3.36 \%, 14.82 \%, 6.66 \%, 23.03 \%, 0.0 \%$ and $3.05 \%$ by different trematoda species respectively. 
Results showed that L. cailliaudi snails were distributed in all of the study sites and harbored trematoda larvae in rate of $36.18 \%, 12.5 \%, 24 \%, 38 \%, 41.8 \%$, and $22.5 \%$ in Shenno, El-Halafy, El-Kafr El-Sharki, Sedi Salem, Motobus and Abioka, respectively.

Results displayed in table (3) revealed that there was marked trematoda-snail specificity, especially for major parasites such as Fasciola, Paramphistomum and Schistosoma. Fasciola species cercariae (Fig. 1-G) were not detected in snails other than the examined Lymnaea cailliaudi. The rate of infection in this snail species reached 45.17\%. Schistosoma species cercariae were shed only from Bulinus and Biomphalaria species. The percentage of infection by this parasite in the examined snails reached to $39.8 \%$ and $65.06 \%$. Three forms of Xiphidio cercariae (Fig. 1-E) were found as common parasite present in most of the examined snail species including L. cailliaudi, Bulinus spp. and B. alexandrina. It worthies to be mentioned that each infected snail harbored only one type of infection in its hepatopancreas. Moreover EMC of Xiphidio type were detected in the tissue of the snail foot (Fig. 1-I) in case of L. cailliaudi, Bulunus spp. and Physa acuta inspected snails (Table 3).

These data showed that cercariae of Fasciola or Shistosoma species were not detected from snails other than their known intermediate hosts (L. cailliaudi, Bulinus and B. alexandrina).

Concerning the other cercariae species found, Paramphistomatidae species cercariae and redia (fig. 1-D) were detected in Bulinus species while Echinostoma species cercariae were shed from Physa acuta snails. During the study, 3 types of Xiphidio cercariae (Fig.1-E) were detected that showed low snail specificity; one type was present in most of the examined snails and was previously described as Xiphidio-cercariae type I , the second type shed from L. cailliaudi, Cleopatra species and Bellamya unicolar snails has been identified previously as Xiphidio cercariae type II; the third type was shed from L. cailliaudi, B. alexandrina and Bellamya unicolar and identified previously as Xiphidio cercariae type C. Moreover type of encysted cercariae (Fig 1-I) were diagnosed in tissue of dissected snails (Table 3).

\subsection{Identification of Fasciola species present in human}

To determine the Fasciola species developed from the eggs isolated from human, enough amounts of the collected eggs were embryonated separately under $26^{\circ} \mathrm{C}$. Most eggs hatched after 16 days. The eggs showed a moderate degree of hatchability that reached to $63 \%$. Miracidia produced were used to induce experimental infection in four separate groups (30 snails each) of 4-5 weeks old laboratory breed L. cailliaudi, L. truncatula, Bulinus truncatus and B. alexandrina snails during June 2012, using an exposure number of 3-5 miracidia / snail.

Dissection of two infected snails from each group at day 6 post infection (PI) revealed the presence of low numbers of senile sporocysts as well as low numbers of juvenile first generation radiae ( ${ }^{\text {st }}$ G.R.) between tissue fragments of the dissected L. cailliaudi snails only. At day 9 PI, the 1st G.R. was extracted from the hepatopancreas of desiccated snails. The $1^{\text {st }}$ G.R. appeared larger in size and the germ cells began to collect together, forming germ balls. Further growth for these germ balls was recorded in snails dissected at day 12 PI. Germ balls inside the $1^{\text {st }}$ G.R increased in size and became more elongated, without constriction at their posterior third, to form daughter rediae (D.R) in snails dissected on $15^{\text {th }}$ day PI.

The second G.R. left first generation rediae and migrated to the snail hepatopancreas at $18^{\text {th }}$ days PI. It appeared small in size (Fig 1-B). At the $22^{\text {th }}$ day PI, the germ balls present inside the first G.R. may be differentiated into elongated form without constriction at their ends, these may be considered as the remnant of germ cells that will produce rediae, while other spherical balls appeared as cercarial embryo with presence of constriction (beginning of tail differentiation) at the end of some of the balls which developed earlier than the small spherical form.

Cercariae in different stages of growth were detected in the large size rediae (mainly of $1^{\text {st }}$ generation group) in infected snails dissected on the $28^{\text {th }}$ day PI (Fig 1-C). On day $28,2^{\text {nd }}$ G.R. was observed that had grown in size and contained early developed cercariae also.

Natural cercarial shedding began on day 41 post infection. Snails dissected at this time contained 3 different sizes and structures of rediae; the first contained developed cercariae shed in the dish. The second one containing daughter radiae shed also in the dish while the $3^{\text {rd }}$ one appears as growing $3^{\text {rd }}$ G.R. redia. It is worthily to be mentioned that the cercariae shed after dissection of snails failed to encyst, while in the naturally shed cercariae the cyst wall developed more rapidly and it is usually completed in a period of 4-8 minutes producing transparent EMC (Fig. 1-H). Mortality in the infected snails was $12 \%$ from the period of parthenitae development until shedding of cercariae.

It was worthily to be mentioned that dissection of L. truncatula, Bulinus truncatus and B. alexandrina snails that were exposed to the same type of Fasciola miracidia simultaneously with L. cailliaudi snails did not show any trematoda parthenita inside it. Also, no mortality was recorded in these snails during the same period.

Concerning Fasciola worms recovered from infected rabbits died or slaughtered at $45^{\text {th }}$ day PI. Seven worms were extracted. All of them had the characteristic features of Fasciola gigantica: an elongated body with parallel body margins and clear difference between the size of the oral and ventral suckers (Fig.1-F). 


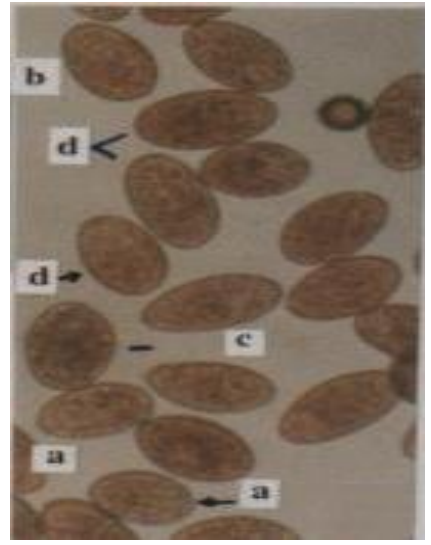

(Fig. 1-A)

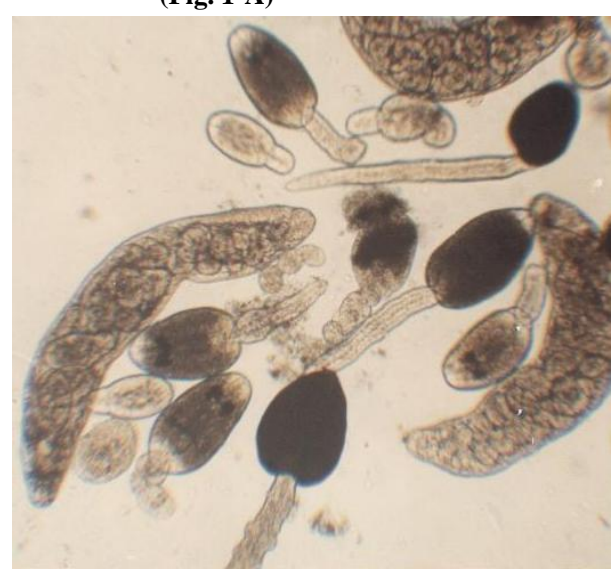

(Fig. 1-D)

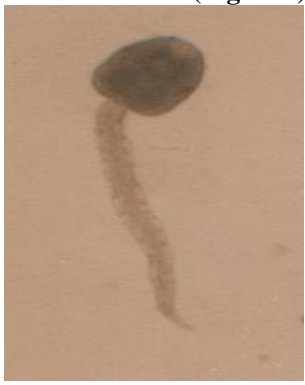

(Fig. 1-G)

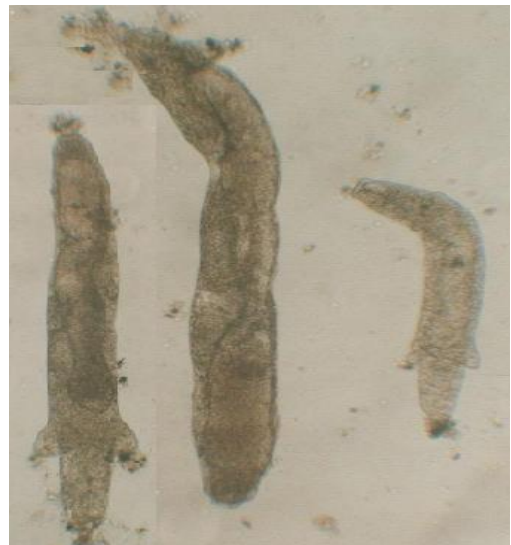

(Fig. 1-B)

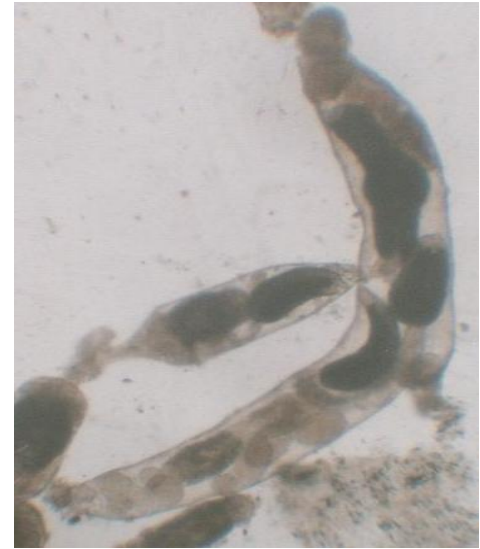

(Fig. 1-C)

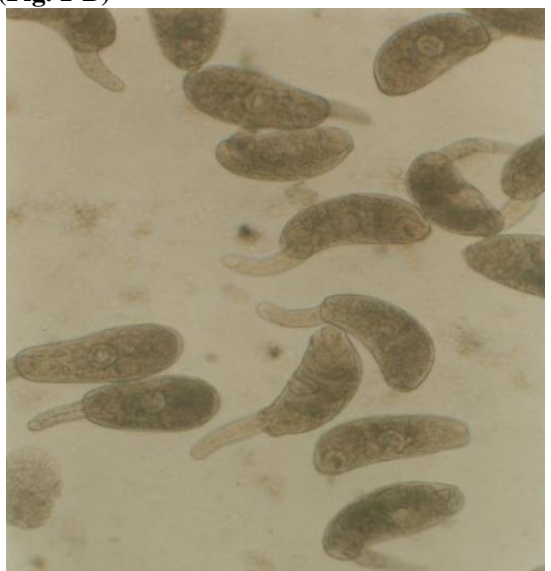

(Fig. 1-E)

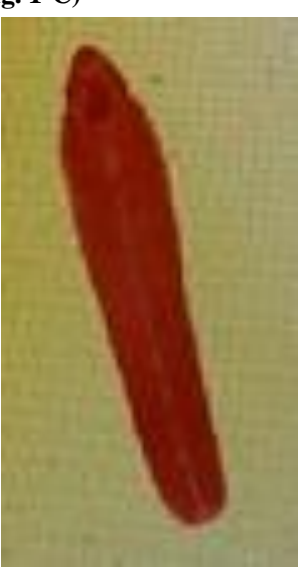

(Fig. 1-F)

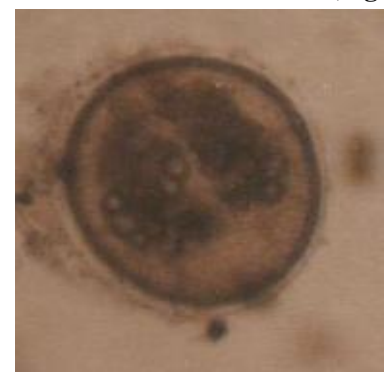

(Fig. 1-H)

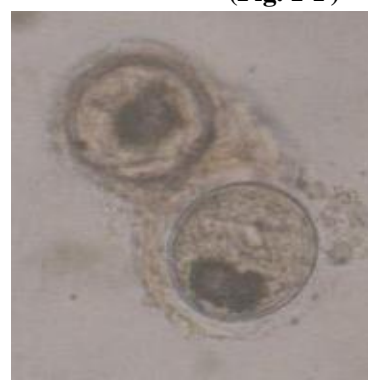

(Fig. 1-I)

Fig. 1: Eggs and Parthenitae Extracted From Examined Laboratory and Field Collected Snails (Fresh Non Mounted Specimens) (1-A)- Fasciola eggs of different sizes, very small (a), medium spherical (b), elongated (c) and large one (d) present in one field collected and purified from stool (X 125).

(1-B)- Three radial generations from experimentally infected $L$. cailliaudi before formation of cercaria at 18th day post infection (X 40)

(1-C) - Formation of cercariae in the 1st generation radia at 28th day P.I. (X40).

(1-D)- Paramphistomum Spp. Radia and Cercaria pigmentata (X 125)

(1-E)- Different views of Xiphidio cercariae type from field collected snails (X 125).

(1-F)- Immature $F$. gigantica worm 45 days old extracted from rabbit, mounted specimen (X20).

(1-G)- Fasciola cercaria shed from laboratory infected L. cailliaudi (X 125).

(1-H) -Rapid encysment of shedded cercariae showing transparent cyst wall (X125).

(1-I) - Type of encysted metacercariae extracted from field collected snails (X100).

Table 1: Incidence of Fasciola Infection among the Examined Stool Samples during the Year

\begin{tabular}{|c|c|c|c|c|c|c|c|c|c|c|c|c|c|c|c|}
\hline \multirow[b]{2}{*}{ District } & \multicolumn{4}{|c|}{ Kafr El-Sheik } & \multirow{2}{*}{\multicolumn{2}{|c|}{$\begin{array}{c}\text { El-Hamool } \\
\text { El-Kafr El- } \\
\text { Shrki }\end{array}$}} & \multirow{2}{*}{\multicolumn{2}{|c|}{$\begin{array}{l}\text { Sedi Salem } \\
\text { Sedi Salem }\end{array}$}} & \multirow{2}{*}{\multicolumn{2}{|c|}{$\begin{array}{l}\text { Motobus } \\
\text { Motobus }\end{array}$}} & \multirow{2}{*}{\multicolumn{2}{|c|}{$\begin{array}{l}\text { Desouk } \\
\text { Abioka }\end{array}$}} & \multirow{2}{*}{\multicolumn{3}{|c|}{ Total }} \\
\hline & \multicolumn{2}{|c|}{ Sheno } & \multicolumn{2}{|c|}{ El-Halafy } & & & & & & & & & & & \\
\hline Season & $\begin{array}{l}\text { No. } \\
\text { Exa } \\
\text { m. }\end{array}$ & $\begin{array}{c}\% \text { of } \\
\text { Fasci } \\
0 \\
\text { Inf }\end{array}$ & $\begin{array}{l}\text { No. } \\
\text { Exam } \\
.\end{array}$ & $\begin{array}{c}\% \text { of } \\
\text { Fasci } \\
o \\
\text { Inf }\end{array}$ & $\begin{array}{l}\text { No. } \\
\text { Exam } \\
\text {. }\end{array}$ & $\begin{array}{c}\% \text { of } \\
\text { Fasci } \\
0 \\
\text { Inf }\end{array}$ & $\begin{array}{c}\text { No. } \\
\text { Exam } \\
\text {. }\end{array}$ & $\begin{array}{c}\% \text { of } \\
\text { Fasci } \\
0 \\
\text { Inf }\end{array}$ & $\begin{array}{c}\text { No. } \\
\text { Exam } \\
.\end{array}$ & $\begin{array}{c}\% \text { of } \\
\text { Fasci } \\
o \\
\text { Inf }\end{array}$ & $\begin{array}{l}\text { No. } \\
\text { Exam }\end{array}$ & $\begin{array}{c}\% \text { of } \\
\text { Fasci } \\
o \\
\text { Inf }\end{array}$ & $\begin{array}{l}\text { No. } \\
\text { Exam }\end{array}$ & $\begin{array}{l}\text { No. } \\
+\mathrm{V} \\
\mathrm{e}\end{array}$ & $\begin{array}{c}\% \text { of } \\
\text { Fascio } \\
\text { Inf }\end{array}$ \\
\hline Winter & 60 & 0.0 & 80 & 3.75 & 80 & 2.5 & 60 & 10 & 60 & 8.33 & 40 & 7.5 & 380 & 19 & 5.0 \\
\hline Spring & 120 & 2.5 & 100 & 6.0 & 100 & 5.0 & 60 & 6.66 & 60 & 10 & 60 & 6.66 & 500 & 28 & 5.66 \\
\hline Summer & 100 & 7.0 & 60 & 3.33 & 120 & 5.0 & 80 & 8.75 & 80 & 7.5 & 80 & 6.25 & 520 & 40 & 7.69 \\
\hline Autumn & 100 & 6.0 & 80 & 5.0 & 70 & 5.7 & 60 & 8.33 & 40 & 0.0 & 60 & 5.0 & 410 & 22 & 5.36 \\
\hline Total & 380 & 6.0 & 320 & 4.68 & 370 & 4.59 & 260 & 8.46 & 240 & 7.08 & 240 & 6.25 & 1810 & 109 & 6.02 \\
\hline
\end{tabular}

$*$ No.Exam. $=$ number of examined fecal and stool samples.

$* \%$ Fas. Inf. $=\%$ of samples showing Fasciola Species eggs 
Table 2: Percentage of Trematoda Infection in the Different Snails Collected From the Study Sites

\begin{tabular}{|c|c|c|c|c|c|c|c|c|c|c|c|c|c|c|c|}
\hline $\begin{array}{l}\text { Name of } \\
\text { District }\end{array}$ & \multicolumn{4}{|c|}{ Kafr El-Sheikh } & \multirow{2}{*}{\multicolumn{2}{|c|}{$\begin{array}{c}\text { El-Hamool } \\
\text { El-Kafr El- } \\
\text { Shrki }\end{array}$}} & \multirow{2}{*}{\multicolumn{2}{|c|}{$\begin{array}{l}\text { Sedi Salem } \\
\text { Sedi Salem }\end{array}$}} & \multirow{2}{*}{\multicolumn{2}{|c|}{$\begin{array}{l}\text { Motobus } \\
\text { Motobus }\end{array}$}} & \multirow{2}{*}{\multicolumn{2}{|c|}{$\frac{\text { Desouk }}{\text { Abioka }}$}} & \multirow{2}{*}{\multicolumn{3}{|c|}{ Total }} \\
\hline & \multicolumn{2}{|c|}{ Sheno } & \multicolumn{2}{|c|}{ El-Halafy } & & & & & & & & & & & \\
\hline Type of snail & $\begin{array}{l}\text { No. } \\
\text { coll- } \\
\text { ect }\end{array}$ & $\begin{array}{l}\text { \% of } \\
\text { Inf. } \\
\text { snail }\end{array}$ & $\begin{array}{l}\text { No. } \\
\text { col- } \\
\text { lect }\end{array}$ & $\begin{array}{l}\% \text { of } \\
\text { Inf. } \\
\text { snail }\end{array}$ & $\begin{array}{l}\text { No. } \\
\text { collect }\end{array}$ & $\begin{array}{l}\% \text { of } \\
\text { Inf. } \\
\text { snail }\end{array}$ & $\begin{array}{l}\text { No. } \\
\text { coll- } \\
\text { ect }\end{array}$ & $\begin{array}{l}\% \text { of } \\
\text { Inf. } \\
\text { snail }\end{array}$ & $\begin{array}{c}\text { No. } \\
\text { coll- } \\
\text { ect }\end{array}$ & $\begin{array}{l}\% \text { of } \\
\text { Inf. } \\
\text { snail }\end{array}$ & $\begin{array}{c}\text { No. } \\
\text { coll- } \\
\text { ect }\end{array}$ & $\begin{array}{c}\% \text { of } \\
\text { Inf. } \\
\text { snail }\end{array}$ & $\begin{array}{c}\text { No. } \\
\text { collect }\end{array}$ & $\begin{array}{c}\text { No. } \\
\text { infec- } \\
\text { ted }\end{array}$ & $\begin{array}{c}\% \text { of } \\
\text { Infected } \\
\text { snail }\end{array}$ \\
\hline $\begin{array}{l}\text { Lymnaea } \\
\text { cailliaudi }\end{array}$ & 1600 & 36.18 & 520 & 12.5 & 636 & 24 & 1192 & 38.0 & 1164 & 41.8 & 1040 & 22.5 & 6152 & 1972 & 32.05 \\
\hline $\begin{array}{l}\text { Lymnaea } \\
\text { alexandrina }\end{array}$ & 76 & 0.0 & 10 & 0.0 & 0.0 & 0.0 & 70 & 0.0 & 52 & 0.0 & 60 & 0.0 & 268 & 00 & 0.0 \\
\hline $\begin{array}{l}\text { Bulinus } \\
\text { species }\end{array}$ & 148 & 11.4 & 20 & 10.0 & 52 & 9.6 & 105 & 12.3 & 101 & 4.8 & 76 & 9.2 & 502 & 59 & 11.75 \\
\hline $\begin{array}{l}\text { Biomphalaria } \\
\text { alexandrina }\end{array}$ & 2800 & 54.0 & 596 & 38.08 & 556 & 36.15 & 2534 & 74.04 & 2480 & 79.03 & 2350 & 66.0 & 11316 & 7327 & 64.74 \\
\hline $\begin{array}{l}\text { Cleopatra } \\
\text { species }\end{array}$ & 290 & 0.0 & 98 & 0.0 & 200 & 0.0 & 300 & 9.0 & 250 & 8.0 & 260 & 0.0 & 1398 & 47 & 3.36 \\
\hline Physa acuta & 2200 & 15.7 & 920 & 12.06 & 1300 & 9.0 & 1700 & 21.0 & 1400 & 23.0 & 1000 & 18.0 & 8520 & 1263 & 14.82 \\
\hline $\begin{array}{l}\text { Melania } \\
\text { tuberculata }\end{array}$ & 55 & 5.45 & 28 & 7.14 & 48 & 12.5 & 115 & 6.95 & 115 & 0.0 & 59 & 0.0 & 420 & 28 & 6.66 \\
\hline $\begin{array}{l}\text { Vivipara } \\
\text { (Bellamya } \\
\text { unicolar) } \\
\end{array}$ & 200 & 22.0 & 105 & 20.0 & 110 & 20.0 & 190 & 24.2 & 200 & 26.0 & 120 & 19.16 & 925 & 2132 & 23.03 \\
\hline $\begin{array}{l}\text { Neritina } \\
\text { nilotica }\end{array}$ & 42 & 0.0 & 0.0 & & 0.0 & 0.0 & 36 & 0.0 & 42 & 0.0 & 12 & 0.0 & 144 & 0.0 & 0.0 \\
\hline $\begin{array}{l}\text { Planorbis } \\
\text { philippi }\end{array}$ & 250 & 0.0 & 230 & 0.0 & 260 & 0.0 & 300 & 0.0 & 300 & 0.0 & 230 & 0.0 & 1570 & 48.0 & 3.05 \\
\hline
\end{tabular}

*No.collect. $=$ number of snails collected.

$* *$ No. infec $=$ number of snails showing trematoda infection $+\%$ of Inf.snail $=\%$ of infected snails.

Table 3: Percentage of Different Types of Trematoda Larvae Detected in All of the Infected Snails Collected During the Year.

\begin{tabular}{|c|c|c|c|c|c|c|c|c|}
\hline \multirow[b]{2}{*}{$\begin{array}{c}\text { Types of the } \\
\text { examined snails }\end{array}$} & \multicolumn{4}{|c|}{ Types and $\%$ of infection by specific cercarial species } & \multicolumn{4}{|c|}{$\begin{array}{l}\text { Types and \% of infection by nonspecific } \\
\text { cercarial species }\end{array}$} \\
\hline & $\begin{array}{l}\text { Fasciola } \\
\text { cercariae }\end{array}$ & $\begin{array}{l}\text { Schistosoma } \\
\text { cercariae }\end{array}$ & $\begin{array}{c}\text { Paramphistomatidae } \\
\text { cercariae }\end{array}$ & $\begin{array}{c}\text { Echinostomatidae } \\
\text { cercariae }\end{array}$ & $\begin{array}{c}\text { Xiphidio } \\
\text { cercariae } \\
\text { (type I) }\end{array}$ & $\begin{array}{l}\text { Xiphidio } \\
\text { cercariae } \\
\text { (type II) }\end{array}$ & $\begin{array}{l}\text { Xiphidio } \\
\text { cercariae } \\
\text { (type C) }\end{array}$ & $\begin{array}{l}\text { Tissue } \\
\text { EMC }\end{array}$ \\
\hline $\begin{array}{l}\text { Lymnaea } \\
\text { cailliaudi }\end{array}$ & $45.17 \%$ & & & & 9.79 & 44.4 & 14.91 & 14.12 \\
\hline Bulinus species & & $39.8 \%$ & $8.33 \%$ & & 26.75 & & & 26.75 \\
\hline $\begin{array}{l}\text { Biomphalaria } \\
\text { alexandrina }\end{array}$ & & $65.06 \%$ & & & 21.18 & & 11.25 & \\
\hline $\begin{array}{l}\text { Cleopatra } \\
\text { species }\end{array}$ & & & & & 47.4 & 2.58 & & \\
\hline Physa acuta & & & & $29.76 \%$ & 70.22 & & & 29.56 \\
\hline $\begin{array}{l}\text { Melania } \\
\text { tuberculata }\end{array}$ & & & & & 50 & & & \\
\hline $\begin{array}{l}\text { Vivipara } \\
\text { (Bellamya } \\
\text { unicolar) }\end{array}$ & & & & & & 14.10 & 85.8 & \\
\hline $\begin{array}{l}\text { Planorbis } \\
\text { philippi }\end{array}$ & & & & & $75 \%$ & & & \\
\hline
\end{tabular}

\section{Discussion}

There are several important morpho-biological and epidemiological differences between $F$. hepatica and $F$. gigantica. The most important aspect is that $F$. gigantica has a prolonged migration period in the liver tissue (90-100 days) before reaching the bile duct and laying eggs [19] as compared to F. hepatica (56-61 days) [20]. Pathological changes that occurred during the liver migrating phase of the fluke were more economically and immunologically dangerous in case of $F$. gigantica in comparison with that of $F$. hepatica, from the aspects of decreases body resistance, and increases their susceptibility to infection by other diseases as well as marked decreasing in general productivity.

The common imported drugs usually are tested against early mature (6-7 weeks old) F. hepatica, while maturation period for $F$. gigantica occurs after 10-12 weeks which may lead to failure in efficacy of the used drug. Some drugs such as Clorsulon, affect flukes depending on enhancing the production of Gamma Amino Butyric acid (GABA) at the nerve ganglia. This neuro-transmitting material is present in $F$. hepatica from the $6-7^{\text {th }}$ weeks of life and in $F$. gigantica at 8-9 weeks old flukes [21]. F. gigantica in Egypt develops in L. cailliaudi and the recorded IMH for F. hepatica is $L$. truncatula. The two snails differ in their morphology and their habitat characteristics [22].

All these facts cleared that it is important to know if infection in human is due to F. gigantica or F. hepatica; to allow accurate early diagnosis and selection of suitable time for treatment especially if this drug was not used against $F$. gigantica before. Moreover, several authors such as Farag and El-Sayed [6] demonstrated that IMH snails for 
Schistosoma were accommodating to transmit human Fasciola. Also Dar et al. [23] mentioned that Radix natalensis is considered to be an essential IMH for $F$. gigantica in Egypt.

The present study was done to spot some light on human fascioliasis in Nile Delta; its species, its IMH snails and tried to answer previous questions about development of Fasciola species in new snail hosts other than that known for animal fascioliasis.

The present study followed diagnosis by direct detection of eggs in stool, this aimed to isolate pure eggs of human origin to complete the other objectives of the work. Recorded Fasciola infection by this way reached up to $6.02 \%$ in the randomly collected samples. This came in agreement with the previously recorded levels in other surrounding districts as $5.6 \%$ in Abis, Alexandria [24] and 10.9\% in El-Sharkia Governorate [25]. Infection rate has no sex or age limits but it depends mainly on the feeding habits of the people and their general hygienic measures.

The high percentage of human infection in Motobus and Sedi Salem agreed with the fact published by Malone [7] where these two sites had low diurnal temperature difference (difference in temperature between day and night) which means that there is more moisture in the area; the condition which helped the continuous persistence of the IMH snail. This rate of infection will be more investigated via another running work that will be published by the same authors in the near future depending on serological and immunological techniques.

Concerning Fasciola egg size, the present study cleared that Fasciola egg size could not be considered as a main point for differentiation between $F$. hepatica and $F$. gigantica, where different egg sizes could be detected in each host. Moreover, some abnormalities could be recorded also. On the other hand, smaller eggs than that previously described for $F$. hepatica as well as larger eggs than that described for $F$. gigantica were extracted. This was supported by the data of previous authors [26], where the egg size for $F$. hepatica (130-150 X 63-90 $\mu$ ) can be included with $F$. gigantica egg size determined by Watannabe [27] (150-173 X 75-88 $\mu)$ and both of them was lower than the size mentioned by Soulsby [19] as F. hepatica egg size was 130-145 X 70-90 $\mu$, and that of $F$. gigantica was 156-197 X 90-104 $\mu$.

On the other hand Malek [20] described strain of $F$. hepatica in Netherlands which can be distinguished by its markedly large eggs that reached to $146-179 \times 80-100 \mu$ in sheep and 143-180 x 88-102 $\mu$ in cattle. El-Zayyat [28] in Egypt measured Fasciola eggs from 28 patients in the same district and determined Fasciola egg size from 130-173X 75-90 $\mu$. Concerning the wide range of egg measurements recorded in the study cases with absence of specific morphological criteria, this revealed that egg size could not be considered as a basic criteria for identification of human Fasciola eggs from that of animal origin. Small size eggs (125-135 X 78-80 $\mu$ ) as well as large size ones were present in other hosts as large sized eggs of human or sheep corresponded to similar sized eggs in buffaloes and donkeys. In the author's opinion the host size and capacity can be considered as a main factors that affect size of fluke and their eggs where a close size relation was clear between eggs of human and that of some animals like sheep also that from large hosts as buffaloes and donkeys, with presence of chance for abnormal egg formation in each case.

Concerning types of trematoda infection recorded in all types of snails collected from the same study sites, the study cleared that there was marked trematoda-snail specificity especially towards the main parasites as Fasciola, Paramphistomum and Schistosoma, where their cercariae were not detected in snails other than their previously known IMH. This came in agreement with two previous studies in the Nile Delta by [11], [16], and in the contrary with the data published by Farag and El-Sayed [6] and Dar et al. [23] about the detection of Fasciola radiae and cercariae in B. alexandrina snails naturally infected in Abis, Alexandria.

In the present study Paramphistomum species redia and its cercaria pigmentata were diagnosed in the examined Bulinus species. The parthenitea of this common ruminant parasite differs from that of Fasciola as its redia has no caudal processes and its cercaria has eye spots, posterior suckers and pigments in its body [19]. This can misdiagnosed with that of Fasciola species if did not exposed to specific diagnosis.

Really development of trematoda in snails isn't considered as an easy way where Bayne et al. [29] mentioned that trematoda immunity in mollusks is cell mediated depending on presence of plasma factor (s) in the resistant snails able to inactivate and lyses the toxic factors released by sporocysts. This factor rendered the sporocysts unable to recognize the nature of the cells encountered and consequently it fails to mount their attack. This factor also facilitates sporocyst damage. In the same respect El-Bahy [30] concluded that the snail overcomes any foreign trematoda infection through stimulation of different types of its haemolymph cells, mainly granulocytes and hyalinocytes-like cells.

These cells form amebofibrous capsules which led to destruction of the foreign invaders at the end with possible involvement of humoral factors also. These previous facts as well as the present study excluded any chance for adaptation or accommodation between snails and new parasites especially with the fact that both of them were present in the same conditions since long time before, and each trematoda species still has its own IMH. On the other hand; the study proved presence of $L$. cailliaudi and Fasciola infection all over the year with marked increase during summer and autumn. Also it was cleared that with the increase of percentage of infection in L. cailliaudi by Fasciola larvae in some of the study sites the level of fascioliasis in the surrounding animals and man increased. Moreover, the fact cleared that there is no need for sharing new snail as IMH in the cycle of the disease.

The detected Xiphidio cercariae and their ability to unspecific encystement in the foot of most fresh water snails in the same aquarium were previously described [11], [16].

Concerning species of Fasciola infect human in this localities, the present study cleared that Fasciola species detected in human in the study sites was Fasciola gigantica. This conclusion depends on several facts including that, the hatched miracidia from the separated Fasciola eggs after incubation period were belonging to F. gigantica species and this comes in agreement with that previously recorded by Soulsby [19] for F. gigantica. 
These miracidia grew successfully in laboratory breed $L$. cailliaudi (the known $F$. gigantica IMH in Egypt) and in the same time didn't grow in the other exposed snails (L. truncatula, B. truncatus and B. alexandrina) under the same laboratory conditions. This came in agreement with that mentioned by Mas-Coma et al. [13] as lymnaeid intermediate hosts of $F$. gigantica are distinguishable from those of $F$. hepatica, morphologically and as for the habitat requirements. Fasciola gigantica snail IMH considered as true aquatic type need permanent water bodies of moderate water current and rich in aquatic vegetations. They added that in central, south and West Africa, L. natalensis is the transmitter, while the synonymous L. cailliaudi is the IMH in East Africa and both of them were closely related to L. auricularia rufescens. The rate of parthenitea development inside the snail and the sequence of radial and cercarial generations came in agreement with that previously described [14] for F. gigantica. Also the early mature fluke extracted from rabbits infected by the produced EMC had the known characters of $F$. gigantica previously described by Soulsby [19]. In the author's opinion; the recorded cases of human fascioliasis in the non-sandy soil areas of Egypt as El-Mansora and Kafer El-sheik cities with no record for the presence of $L$. truncatula snail, must be due to an infection by $F$. gigantica, this came in agreement with Malek [20] where he mentioned that both species of Fasciola have been found in human.

\section{References}

[1] R.W. Tolan, Fascioliasis due to F. hepatica and F. gigantica infection: an Update on this "Neglected" Tropical Disease, LABMEDICINE 42 (2) (2011) $107-115$.

[2] J. Keiser, J. Utzinger, Food-borne trematodiases, Clin. Microbiol. Rev. 22 (2009) 166-483.

[3] M.E. Ali, M.H. El-Kannishy, E.S. El-Kholy, M.M. Hegazy, A.A. Khashaba, M.R. Rifaay, M.A. Rifaat, Human fascioliasis in Dakahlia Governorate, Mansora, Med. Bull. 3 (1974) 295.

[4] E. Safar, E. Mikhail, G. Bassiouni, S. El-Bassiouni, H. El-Kholy, Human fascioliasis in some areas in Cairo \& Giza Governorates, Egypt, J. Egypt. Soc. Parasitol. 35 (1) (2005) 181-192.

[5] M.A. Valero, M.V. Periago, I. Perez-Crespo, E. Rodriguez, Assessing the validity of an ELISA test for the serological diagnosis of human fascioliasis in different epidemical situations, Trop. Med. Internat. Health 17 (5) (2012) 630-636.

[6] H.E. Farag, M.H. El-Sayed, Biomphalaria alexandrina naturally infected with F. gigantica in Egypt, Trans. R. Soc. Trop. Med. Hyg. 89 (1) (1995) 36.

[7] J.B. Malone, O.K. Huh, D.P. Fehler, A.I. El-Magdoub, Temperature data from satellite imagery and the distribution of schistosomiasis in Egypt, Am. J. Trop. Med. Hyg. 50 (6) (1992) 714-722.

[8] J.B. Malone, R.T. Ramsey, A.F. Loyacano, Efficacy of clorsulon for the treatment of mature naturally acquired and 8 weeks old experimentally induced F. hepatica infection in cattle, Am. J. Vet. Res. 45 (5) (1984) 851-854.

[9] A.N. Hussein, I.M. Hassan, M.A. Kalifa, Description of eggs and larval stages of Fasciola, light and scanning electron microscopic studies, Research J. Parasitol. 5 (1) (2010) 1-12.

[10] M.H. Pritchard, G.O.W. Kruse, The collection and preservation of animal parasites, University of Nebraska Press, Library of Congress Cataloging in Publication Data, Lincoln, (1982) pp 29.

[11] M.R. Diab, Biological studies on trematode larvae and fresh water snails, M.V.Sc. (thesis) Fac.Vet. Med. Alexandria University, (1993).

[12] D.S. Brown, Fresh water snails of Africa and their medical importance, 2nd ed., Taylor and Francis Ltd., 4 John St., London, WCIN (1994).

[13] S. Mas-Coma, M.A. Valero, M.D. Bargues, Chapter 2 Fasciola, lymnaeids and human fascioliasis, with a global overview on disease transmission, epidemiology, evolutionary genetics molecular epidemiology and control, Adv. in Parasitol. (69) (2009) 41-146.

[14] M.M. El-Bahy, Effect of some biotic and abiotic factors on Fasciola infection in both intermediate and final hosts, Ph.D. V.Sc. (thesis) Fac. Vet. Med. Cairo University (1988).

[15] F.A. Abdel Ghani, Studies on life cycle of some trematodes of egyptian domesticated animals, Ph.D. V.Sc. (thesis) Fac. Vet. Med. Cairo University (1955).

[16] M.T. Atwa, Studies on some trematode larvae of some fresh water snails in Fayoum Governorate, Egypt. Ph.D, .S. Sc. (thesis) Fac. Science, Animal science Dept. Fayoum University, Egypt (2012).

[17] C.P. De Souzal, K.G. Magalhaes, L.K. Jannotti, N. Katz, Aspects of the maintenance of the life cycle of F. hepatica in Lymnaea columella ion Minas Greais, Brazil, Mem. Inst. Oswaldo Cruz, Rio de Janero 97 (3) (2002) 407-410.

[18] M.V. Periago, M.A. Valero, M. El Sayed, et al., First phenotypic description of Fasciola hepatica/Fasciola gigantica intermediate forms from the human endemic area of the Nile Delta, Egypt, Infect Genet and Evol (8) (2008) 51-58.

[19] E.J. Soulsby, Helminthes arthropods \& protozoa of domesticated animals, 7th ed., Baillere, Tindall and Casell Ltd., London, Philadelphia Toronto (1986).

[20] E.A. Malek, Snails transmitted parasitic diseases, Library of Congress Cataloging in Publication Data, Boca Raton, USA II, (1980) 131-170.

[21] M.S. Abdel-Rahman, H.M. Omar, M.M. El-Bahy, E.I. Ramadan, Fasciolicidal effect of Ivomec-F against immature F. gigantica in experimentally infested buffalo calves, Proc. 2nd Cong. Fac. Vet. Med. Cairo Univ. (1992).

[22] S. Mas-Coma, J.G. Esteban, M.D. Bargues, Epidemiology of human fascioliasis: a review and proposed new classification. Bulletin of the World Health Organization 77 (4) (1999) 340 - 346.

[23] Y.D. Dar, D. Rondelaud, G. Dreyfuss, Update of fasciolosis-transmitting snails in Egypt (review and comment), J. Egypt. Soc. Parasitol. 35 (2) (2005) 477-490.

[24] H.E. Farag, P.M. Barkat, M. Ragab, E. Omar, A focus of human fascioliasis in the Nile Delta, Egypt, J. Trop. Med. Hyg. 82 (1979) 188-190.

[25] M.M. Hassan, N.E. Moustafa, L.A. Mahmoud, B.E. Abbaza, M.H. Hegab, Prevalence of Fasciola infection among school children in Sharkia Governorate, Egypt, J. Egypt. Soc. Parasitol. 25 (2) (1995) 543-549.

[26] M.A. Valero, I. Perez-Crespo, V. Periago, S. Mas-Coma, Fluke egg characteristics for the diagnosis of human and animal fascioliasis by F. Hepatica and F. gigantica, Acta Trop. 111 (2) (2009) 150-159.

[27] S. Watanabe, A revision of the genus Fasciola in Japan with particular reference to F. hepatica and F. gigantica, Progress of Medical Parasitology in Japan, Vol. II, Megura Parasitological Museum, Tokyo, (1965) 359-381.

[28] E.A. El-Zayyat, Evaluation of crude and purified Fasciola antigens in immunological diagnosis of human fascioliasis. M.D. degree in Medical Science, department of Parasitology Faculty of Medicine (Thesis), Ain Shams University, Cairo, (1989).

[29] C.J. Bayen, P.M. Buckley, and P.C. De Wan, Schistosoma mansoni: cytotoxicity of hemocytes from susceptible snail hosts for sporocysts in plasma from resistant B. glabrata, Experimental Parasitology 50 (1980) 409-416.

[30] M.M. El-Bahy, Studies on the antagonistic effect of some trematode larvae inside their intermediate hosts. Ph.D. V.Sc. (thesis) Fac.Vet. Med. Cairo University, (1993). 